
Not for reproduction, distribution or commercial use.

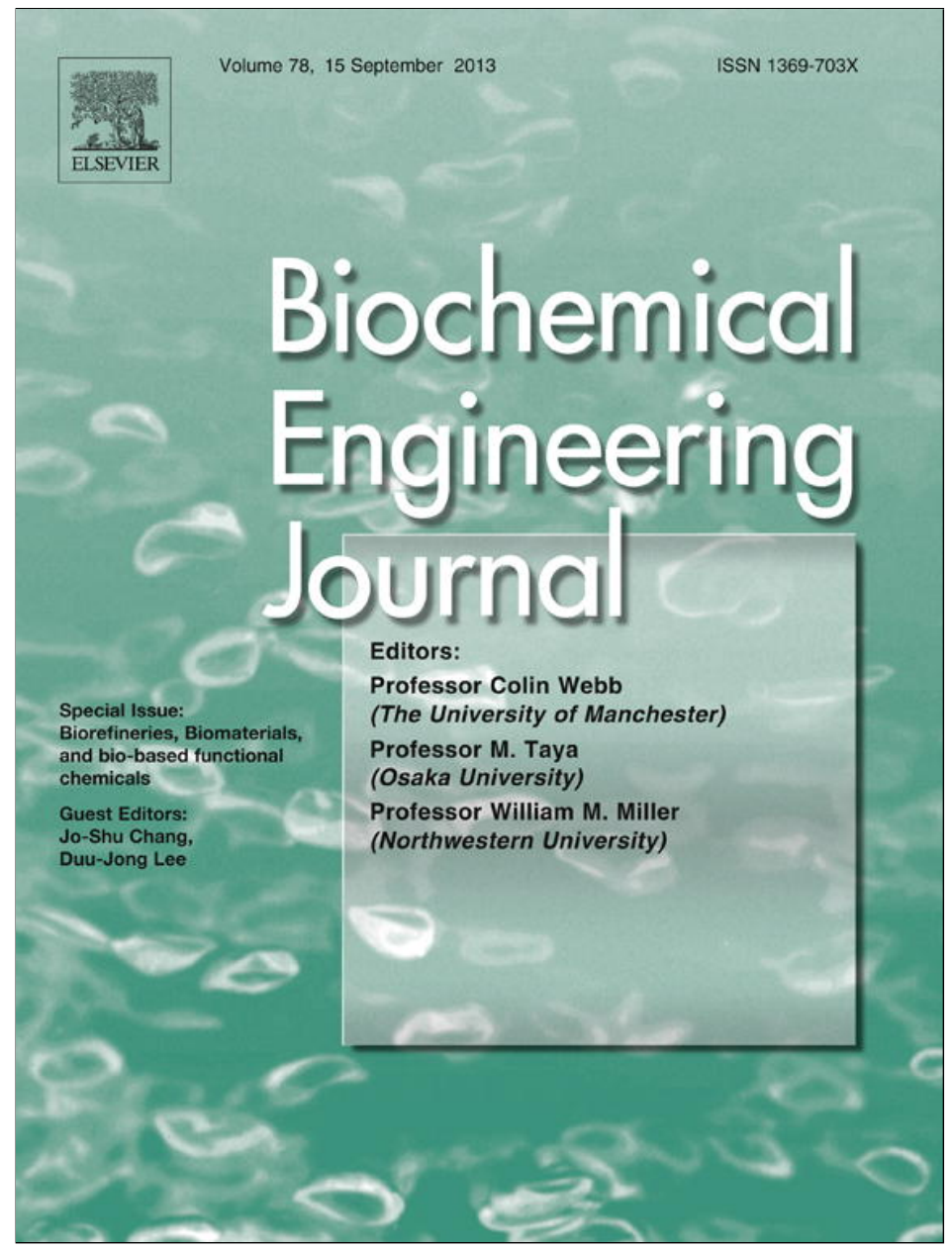

This article appeared in a journal published by Elsevier. The attached copy is furnished to the author for internal non-commercial research and education use, including for instruction at the authors institution and sharing with colleagues.

Other uses, including reproduction and distribution, or selling or licensing copies, or posting to personal, institutional or third party websites are prohibited.

In most cases authors are permitted to post their version of the article (e.g. in Word or Tex form) to their personal website or institutional repository. Authors requiring further information regarding Elsevier's archiving and manuscript policies are encouraged to visit: 


\title{
Subcritical water and dilute acid pretreatments for bioethanol production from Melaleuca leucadendron shedding bark
}

\author{
Ibrahim Nasser Ahmed ${ }^{a}$, Sylviana Sutanto ${ }^{a}$, Lien Huong Huynh ${ }^{b}$, Suryadi Ismadji ${ }^{c}$, \\ Yi-Hsu Ju ${ }^{\mathrm{a}, *}$ \\ a Department of Chemical Engineering, National Taiwan University of Science and Technology, 43 Keelung Rd., Sec. 4, Taipei 106-07, Taiwan \\ ${ }^{\mathrm{b}}$ Department of Chemical Engineering, Can Tho University, 3-2 Street, Can Tho City, Viet Nam \\ ${ }^{c}$ Department of Chemical Engineering, Widya Mandala Surabaya Catholic University, Kalijudan 37, Surabaya 60114, Indonesia
}

\section{A R T I C L E I N F O}

\section{Article history:}

Received 18 September 2012

Received in revised form 6 February 2013

Accepted 9 March 2013

Available online 15 March 2013

\section{Keywords:}

Glucose

Cellulase

Fermentation

Ethanol

Subcritical water

Melaleuca leucadendron

\begin{abstract}
A B S T R A C T
The feasibility of bioethanol production using the lignocellulose of the shedding bark of Melaleuca leucadendron (Paper bark tree) was investigated. The effects of pretreatment parameters (temperature, time and acid concentration) on the yields of sugars and inhibitors, and optimal pretreatment conditions were determined. At very low severity conditions (combined severity factor, CSF $\leq 0.335$ ), $28 \%$ of xylan was recovered and this recovery increased with increasing CSF till it peaked to $64.4 \%\left(11.2 \mathrm{gxylose}^{-1}\right)$ at a CSF of 1.475 . However, at CSF $>2.0$, xylose yield declined due to degradation. Mild and progressive glucose yield was detected in prehydrolysate at $\mathrm{CSF} \geq 1.514$, and subsequent enzymatic hydrolysis allowed complete glucan solubilization. Implementing environmentally friendly subcritical water pretreatment at $\mathrm{CSF} \leq 0.335$ on the shedding bark, about $85 \%$ of glucan solubilization was achieved after enzymatic hydrolysis. An industrial Saccharomyces cerevisiae strain readily fermented crude hydrolysate within $12 \mathrm{~h}$, yielding $24.7 \mathrm{~g} \mathrm{~L}^{-1}$ ethanol at an inoculum size of $2 \%(\mathrm{v} / \mathrm{v})$, representing a glucose to ethanol conversion rate of $0.475 \mathrm{~g} \mathrm{~g}^{-1}$ ( $91 \%$ ethanol yield). Based on our findings, the shedding bark is a potential feedstock for bio-ethanol production.
\end{abstract}

(C) 2013 Elsevier B.V. All rights reserved.

\section{Introduction}

Bioethanol has the potential as a supplement and/or replacement for gasoline. Currently most bioethanol is produced from starch and sugar producing crops. However, non-food plant sources like lignocellulosic biomass are far more abundant and cheaper. Among available lignocelluloses, wood and agricultural residues which have the advantage of being widely available are one of the better feedstock options, partly due to their higher cellulose content and compositional uniformity. Moreover, tree possesses a lignocellulosic energy conversion factor of 16 (compared to 1 and 8 for corn and sugarcane, respectively), and can be grown on marginal land, thereby minimizing encroachment on land for growing food crops [1]. Thus the conversion of lignocellulosic biomass to fuel offers potential economical and environmental advantage.

Lignocellulose consists of lignin (15-30\%), and carbohydrates such as cellulose (41-53\%) and hemicelluloses (14-35\%), and minor components like proteins, ash, salt and minerals [2,3]. The challenge in using trees bark or hardwoods as a feedstock is the difficulty associated with liberating cellulose from its lignin seal,

\footnotetext{
* Corresponding author. Tel.: +886 2 27376612; fax: +8862 27376644 .

E-mail address: yhju@mail.ntust.edu.tw (Y.-H. Ju).
}

which is by far the most costly step of lignocellulose utilization, strongly affecting success and feasibility of prior and subsequent operations [4]. Although pretreatment is costly, it costs more without pretreatment [5]. Depending on specific pretreatment, different effects may be observed on the substrate that can all contribute to improving hydrolysis. Some of these effects are: removal of some or all of the lignin which causes increased porosity in the substrate [6]; disruption of the lignin structure and its linkages with the rest of biomass; removal of hemicellulose that hampers access of cellulase to cellulose; disruption of the hemicellulose structure; reduction in the crystallinity of cellulose; reduction in the degree of polymerization of cellulose and reduction in the size of particles [7]. The current choice of pretreatment method for lignocellulose material for ethanol production is dilute acid hydrolysis at moderate to high temperatures [8] and subcritical water (SCW) treatment $[9,10]$. SCW is defined as hot water at temperatures ranging between 100 and $374{ }^{\circ} \mathrm{C}$ under high pressure to maintain water in liquid state. It has been widely used for hydrolyzing organic compounds. Recently growing attention has led to extensive research activities using SCW for hydrolysis and conversion of bio-mass and carbohydrates to useful compounds [11-15]. On the other hand, dilute acid pretreatment predominantly solubilizes the hemicellulose fraction and disrupts the crystalline structure of cellulose fibrils, which favors fast enzymatic hydrolysis [16]. However, acid pretreatment 
can result in the formation of polysaccharide degradation products that are often inhibitory to downstream fermentation organisms and lower the overall sugar yields $[17,18]$. In addition the performance of different pretreatments may vary with feedstock types hence it is important to study the effect of pretreatment on potential lignocellulose biomass.

Melaleuca leucadendron (Paper-bark Tree, PBT) is a native Australian tree and now grown worldwide. The tree has grayish white, layered bark that is continually shed, exposing the whiter inner part. The bark feels soft like sponge. It has high adaptability and can grow well in poor soil, dry or submerged environments, and resists pests and pollution. To the best of our knowledge, there is no report on bioethanol production from the pretreated shedding bark of PBT. The objective of this study was to produce ethanol from pretreated PBT shedding barks. The study can be summarized into three parts: (1) to investigate the effects of pretreatments variables (acid concentration, temperature and time) on sugar release, inhibitors generation and morphology of biomass. (2) To understand the effect of pretreatment on the enzymatic saccharification of the biomass; and (3) to evaluate the fermentation potential of sugar containing hydrolysates for bioethanol production.

\section{Materials and methods}

\subsection{Materials}

Shedding bark of PBT was collected from experimental farm of National Taiwan University, Da'an District, Taipei, Taiwan. The location of the farm is $\mathrm{N} 25^{\circ} 00^{\prime} 59.40^{\prime \prime}$; E121 ${ }^{\circ} 32^{\prime} 25.1^{\prime \prime}$. The air dried bark was ground by a blender and passed through a sieve with mesh no. 60. Cellulases and Novozyme 188 (from Aspergillus niger) with an activity of $0.3 \mathrm{U} \mathrm{mg}^{-1}$ and $250 \mathrm{IU} \mathrm{mL}^{-1}$, respectively were purchased from Sigma company.

\subsection{Experimental design and Statistical analysis}

A $4 \times 3 \times 3$ factorial design was implemented for evaluating the effects of three pretreatment parameters: dilute sulfuric acid concentration $(0 \%, 0.5 \%, 1 \%$, and $2 \%, \mathrm{v} / \mathrm{v})$, pretreatment temperature $\left(120,140\right.$ and $\left.160^{\circ} \mathrm{C}\right)$ and pretreatment time (15, 30 and $\left.60 \mathrm{~min}\right)$ on yield of sugars and inhibitors and to identify optimal pretreatment conditions. A sulfuric acid concentration of $0 \%$ refers to subcritical water (SCW) pretreatment. The four levels of acid concentration $\left(X_{1}\right)$ were represented by $0,1,2$ and 3 , and the three levels of temperature $\left(X_{2}\right)$ and time $\left(X_{3}\right)$ each were represented by 0,1 and 2 . A total of 36 runs were done and an overall experimental design is summarized in Table 1. Pretreatment values were chosen on the basis of previous works carried out on other lignocellulosic biomass $[19,20]$ with slight modification. The statistical significance difference among experimental result was checked by using a $t$-test with the level of significance $P<0.05$.

For the purpose of pretreatment optimization, the concentration $\left(\mathrm{g} \mathrm{L}^{-1}\right)$ of glucose, xylose, HMF and furfural of the prehydrolysate were the responses. Regression analysis was performed to estimate the effect of independent variables (acid concentration, temperature and time) on the responses by using statistical software of Minitab-16. Each response was tested for possible linear, quadratic and cubic models to find out the best fitting model. Cubic model was used to calculate regression coefficients for xylose, and full quadratic polynomial model was used for HMF, furfural and glucose. Backward elimination strategy was used to eliminate insignificant terms from the model. Significance of each model term was determined with analysis of variance (ANOVA). The fit of the models were evaluated by the value of $\mathrm{R}^{2}$. Contours were plotted based on the final equation in order to find out interaction and to determine optimum level of each variable for pretreatment.

\subsection{Pretreatment}

Bark sample at a solid loading of $10 \%\left(\mathrm{~g} \mathrm{~mL}^{-1}\right)$ was soaked in sulfuric acid $(0 \%, 0.5 \%, 1 \%$ or $2 \%, v / v)$. There are three main parts in the equipment for pretreatment: reactor, heater and control devices. The reactor is made of stainless steel with a total inner volume of about $200 \mathrm{~mL}$. It is $25 \mathrm{~mm}$ thick and can withstand an estimated maximum operation pressure of $100 \mathrm{MPa}$. The reactor is equipped with a thermocouple and a pressure gauge. The process was run under batch mode. For subcritical treatment, nitrogen gas $(99.9 \%$ purity) purchased from Dong-Xing Company (Taiwan) was used to maintain constant pressure (10 bar) in the reactor.

In SCW pretreatment, after a predetermined time $(15,30$ or $60 \mathrm{~min}$ ), subcritical condition was terminated immediately by venting vapor in the reactor. The reactor was rapidly cooled to room temperature and the slurry collected from the reactor was immediately filtered. The filtrate was stored at $4{ }^{\circ} \mathrm{C}$ for further analysis of its monomeric sugar (glucose, xylose) and inhibitors (HMF and Furfural) contents. The collected solid was washed with deionized (DI) water and kept at $4{ }^{\circ} \mathrm{C}$.

\subsection{Combined severity factor}

The combined severity parameter facilitates comparison of a broad range of data by coupling the reaction conditions of time, temperature, and acid concentration into a single variable. The severity factor, $R_{0}$, is defined as [21]:

$R_{0}=t \exp \left[\frac{\left(T_{\mathrm{H}}-T_{\mathrm{R}}\right)}{14.75}\right]$

where $t$ is pretreatment time in $\min , T_{\mathrm{H}}$ is the pretreatment temperature in ${ }^{\circ} \mathrm{C}$, and $T_{\mathrm{R}}$ is a reference temperature, most often $100^{\circ} \mathrm{C}$. To include the effect of dilute acid, the combined severity factor (CSF) has been used [22]:

$\log \mathrm{CSF}=\log R_{\mathrm{o}}-\mathrm{pH}$

In this study, CSF of pretreatment varied from -1.515 to 2.885 (Table 1).

\subsection{Scanning electron microscope (SEM) analysis}

Structural differences in the morphology of PBT bark before and after pretreatment were examined by using a JEOL JSM-6390LV SEM [23]. The pretreated solid specimen were dehydrated using a freeze dryer (LABCONCO, 2.5 Free Zone, USA) since lyophilization preserves morphology [24]. Prior to imaging, specimens were mounted on a conductive tape and coated with platinum using a JEOL JFC-1300 auto fine coater to make the fibers conductive, and to avoid buildup of charge on the specimen. Imaging was done using a voltage of $10 \mathrm{kV}$ at $500 \times$ magnification.

\subsection{Enzymatic saccharification}

Enzyme isodose saccharifications were done for all solid residues recovered from $S C W$ and acid pretreatments after adjusted to $\mathrm{pH} 4.8$ using $\mathrm{Ca}(\mathrm{OH})_{2}$. A mixture of cellulase and $\beta$-glucosidase (Novozyme 188 from $A$. niger) were used at $50^{\circ} \mathrm{C}$ for $72 \mathrm{~h}$ in a water bath shaker $(200 \mathrm{rpm})$. $\beta$-Glucosidase was used to supplement the insufficient $\beta$-glucosidase activity in cellulases. Sodium citrate buffer was used to maintain mixture $\mathrm{pH}$ at 4.8 . The enzyme loadings were: Cellulases $33 \mathrm{FPU}, \beta$-glucosidase $66 \mathrm{CBU} \mathrm{g}^{-1}$ pretreated dry biomass. Hydrolysis was performed at $50{ }^{\circ} \mathrm{C}$ on a rotating wheel at $200 \mathrm{rpm}$ for $72 \mathrm{~h}$. The hydrolysate samples were centrifuged $(3500 \times \mathrm{g}, 5 \mathrm{~min})$, filtered and stored at $-20^{\circ} \mathrm{C}$. 
Table 1

Experimental design of PBT shedding bark pretreatment with code values of the parameters, and associated combined severity factor, CSF.

\begin{tabular}{|c|c|c|c|c|c|c|c|c|}
\hline \multirow[t]{2}{*}{ No. } & \multicolumn{3}{|c|}{ Pretreatment parameters } & \multicolumn{3}{|c|}{ Code values $^{\mathrm{a}}$} & \multirow[t]{2}{*}{$\mathrm{pH}$} & \multirow[t]{2}{*}{ CSF } \\
\hline & $\mathrm{H}_{2} \mathrm{SO}_{4}(\%, \mathrm{v} / \mathrm{v})$ & Temp. $\left({ }^{\circ} \mathrm{C}\right)$ & Time (min) & $X_{1}$ & $X_{2}$ & $X_{3}$ & & \\
\hline 1 & 0 & 120 & 15 & 0 & 0 & 0 & 3.28 & -1.515 \\
\hline 2 & 0 & 120 & 30 & 0 & 0 & 1 & 3.26 & -1.194 \\
\hline 3 & 0 & 120 & 60 & 0 & 0 & 2 & 3.22 & -0.853 \\
\hline 4 & 0 & 140 & 15 & 0 & 1 & 0 & 3.2 & -0.816 \\
\hline 5 & 0 & 140 & 30 & 0 & 1 & 1 & 3.15 & -0.495 \\
\hline 6 & 0 & 140 & 60 & 0 & 1 & 2 & 3.17 & -0.244 \\
\hline 7 & 0 & 160 & 15 & 0 & 2 & 0 & 3.25 & -0.307 \\
\hline 8 & 0 & 160 & 30 & 0 & 2 & 1 & 3.26 & 0.0004 \\
\hline 9 & 0 & 160 & 60 & 0 & 2 & 2 & 3.25 & 0.335 \\
\hline 10 & 0.5 & 120 & 15 & 1 & 0 & 0 & 0.98 & 0.78 \\
\hline 11 & 0.5 & 120 & 30 & 1 & 0 & 1 & 1.05 & 1.016 \\
\hline 12 & 0.5 & 120 & 60 & 1 & 0 & 2 & 1.02 & 1.347 \\
\hline 13 & 0.5 & 140 & 15 & 1 & 1 & 0 & 1.03 & 1.324 \\
\hline 14 & 0.5 & 140 & 30 & 1 & 1 & 1 & 1.17 & 1.475 \\
\hline 15 & 0.5 & 140 & 60 & 1 & 1 & 2 & 1.08 & 1.8759 \\
\hline 16 & 0.5 & 160 & 15 & 1 & 2 & 0 & 1.02 & 1.923 \\
\hline 17 & 0.5 & 160 & 30 & 1 & 2 & 1 & 1.19 & 2.074 \\
\hline 18 & 0.5 & 160 & 60 & 1 & 2 & 2 & 1.17 & 2.355 \\
\hline 19 & 1 & 120 & 15 & 2 & 0 & 0 & 0.87 & 0.895 \\
\hline 20 & 1 & 120 & 30 & 2 & 0 & 1 & 0.9 & 1.146 \\
\hline 21 & 1 & 120 & 60 & 2 & 0 & 2 & 0.89 & 1.477 \\
\hline 22 & 1 & 140 & 15 & 2 & 1 & 0 & 0.84 & 1.514 \\
\hline 23 & 1 & 140 & 30 & 2 & 1 & 1 & 0.86 & 1.795 \\
\hline 24 & 1 & 140 & 60 & 2 & 1 & 2 & 0.93 & 2.016 \\
\hline 25 & 1 & 160 & 15 & 2 & 2 & 0 & 0.82 & 2.123 \\
\hline 26 & 1 & 160 & 30 & 2 & 2 & 1 & 0.81 & 2.434 \\
\hline 27 & 1 & 160 & 60 & 2 & 2 & 2 & 0.95 & 2.595 \\
\hline 28 & 2 & 120 & 15 & 3 & 0 & 0 & 0.7 & 1.065 \\
\hline 29 & 2 & 120 & 30 & 3 & 0 & 1 & 0.69 & 1.406 \\
\hline 30 & 2 & 120 & 60 & 3 & 0 & 2 & 0.66 & 1.707 \\
\hline 31 & 2 & 140 & 15 & 3 & 1 & 0 & 0.77 & 1.584 \\
\hline 32 & 2 & 140 & 30 & 3 & 1 & 1 & 0.72 & 1.935 \\
\hline 33 & 2 & 140 & 60 & 3 & 1 & 2 & 0.67 & 2.286 \\
\hline 34 & 2 & 160 & 15 & 3 & 2 & 0 & 0.72 & 2.223 \\
\hline 35 & 2 & 160 & 30 & 3 & 2 & 1 & 0.7 & 2.584 \\
\hline 36 & 2 & 160 & 60 & 3 & 2 & 2 & 0.66 & 2.885 \\
\hline
\end{tabular}

a Code represent $\mathrm{H}_{2} \mathrm{SO}_{4}$ is $X_{1}$; temperature is $X_{2}$ and time is $X_{3}$. Code values represent by 0 is low level, 3 is high level for $X_{1}$. And 0 is low level, 1 is central level, 2 is high level for $X_{2}$ and $X_{3}$.

\subsection{Composition analysis}

Specific structural carbohydrates and lignin composition of air dried native PBT shedding bark sample were determined using the standard NREL method as described by Sluiter et al. [25]. Likewise the ash and moisture contents were determined and a two-step extraction process was performed to quantify extractives using NREL procedure [26].

The contents of glucose and xylose in the filtrate from pretreatment and hydrolysate were determined by using a high performance liquid chromatography, HPLC (Jasco, Japan) equipped with Jasco 830-RI Intelligent RI detector and a Cosmosil sugar-D column $(4.6 \mathrm{~mm}$ I.D. $\times 250 \mathrm{~mm})$. Acetonitrile: water $(80: 20, \mathrm{v} / \mathrm{v})$ was used as the mobile phase at a flow rate of $1.0 \mathrm{~mL} \mathrm{~min}^{-1}$. The concentrations of 5-hydroxymethylfurfural (HMF) and furfural were analyzed by HPLC (Jasco, Japan) equipped with a PU-2089 pump, a degasser, an UV-2077 detector and a Luna C-18 column $(5 \mu \mathrm{m}$ particle size, $250 \mathrm{~mm} \times 4.6 \mathrm{~mm}$, Phenomenex, USA). The sample was diluted appropriately with deionized water, filtered through a $0.22 \mu \mathrm{m}$ PVDF syringe filter (Testhigh) and then injected into the column under the conditions: $25^{\circ} \mathrm{C}$ column temperature, mobile phase acetonitrile: water: acetic acid $(11: 88: 1, \mathrm{v} / \mathrm{v} / \mathrm{v})$ with a flow rate of $1 \mathrm{~mL} \mathrm{~min}^{-1}, 25 \mu \mathrm{L}$ injection volume and $276 \mathrm{~nm}$ absorption wavelength. Finally, the concentrations of D-glucose, D-xylose, furfural and HMF was calculated by using calibration curves obtained from standard D-glucose, D-xylose, furfural and HMF solutions, respectively. Ethanol content was determined by gas chromatography (GC-14B, Shimadzu, Japan) with a flame ionization detector after the sample was centrifuged at $13,000 \times g$ and the supernatant was filtered using $0.22 \mu \mathrm{m}$ PES membrane filters (Pall, USA). Other conditions of operation were: nitrogen as mobile phase $\left(30 \mathrm{ml} \mathrm{min}^{-1}\right)$, column temperature $40^{\circ} \mathrm{C}$, injector temperature $20{ }^{\circ} \mathrm{C}$ and injection volume $1 \mu \mathrm{L}$. The concentrations of ethanol were calculated based on elution time and peak areas of known concentration of ethanol. Separations were carried out on a column stabilwax $^{\circledR}$ - DA (fused silica, polar phase; crossbond $^{\circledR}$ carbowax $^{\circledR}$ polyethylene glycol).

\subsection{Fermentation}

Ethanol Red ${ }^{\circledR}$ Saccharomyces cerevisiae was used in the fermentation studies and was routinely cultured at $30^{\circ} \mathrm{C}$ on YPD agar plates $\left(20 \mathrm{~g} \mathrm{~L}^{-1}\right.$ glucose, $20 \mathrm{~g} \mathrm{~L}^{-1}$ peptone, $10 \mathrm{~g} \mathrm{~L}^{-1}$ yeast extract and $16 \mathrm{~g} \mathrm{~L}^{-1}$ agar). Hydrolysate obtained from PBT bark at various CSF was combined and adjusted to $\mathrm{pH} 5.05$ using $\mathrm{Ca}(\mathrm{OH})_{2}$ and glucose concentration was adjusted to $52 \mathrm{~g} \mathrm{~L}^{-1}$. Any un-hydrolyzed fiber and gypsum $\left(\mathrm{CaSO}_{4}\right)$ was removed by filtration $(0.22 \mu \mathrm{m})$ prior to use. Inoculums for yeast shake-flask studies were prepared by selecting a single colony from YPD culture plates and inoculating into $40 \mathrm{~mL}$ pre-seed medium. The media consisted of $20 \mathrm{~mL}$ YPD broth, $20 \mathrm{~mL}$ filter-sterilized hydrolysate containing $2 \mathrm{~g} \mathrm{~L}^{-1}$ $\mathrm{KH}_{2} \mathrm{PO}_{4}, 5 \mathrm{~g} \mathrm{~L}^{-1}$ yeast extract, $10 \mathrm{~g} \mathrm{~L}^{-1}$ peptone and $1 \mathrm{gL}^{-1} \mathrm{MgSO}_{4}$ at $\mathrm{pH} 5.05$. After incubation at $30^{\circ} \mathrm{C}$ for $24 \mathrm{~h}$, the optical density (OD 660) reading of the seed culture reached between 0.8 and 1.0. Aliquots ( $1 \%, 2 \%, 5 \%$ and $10 \%, v / v)$ were used to inoculate the main fermentation medium independently. The yeast fermentation 


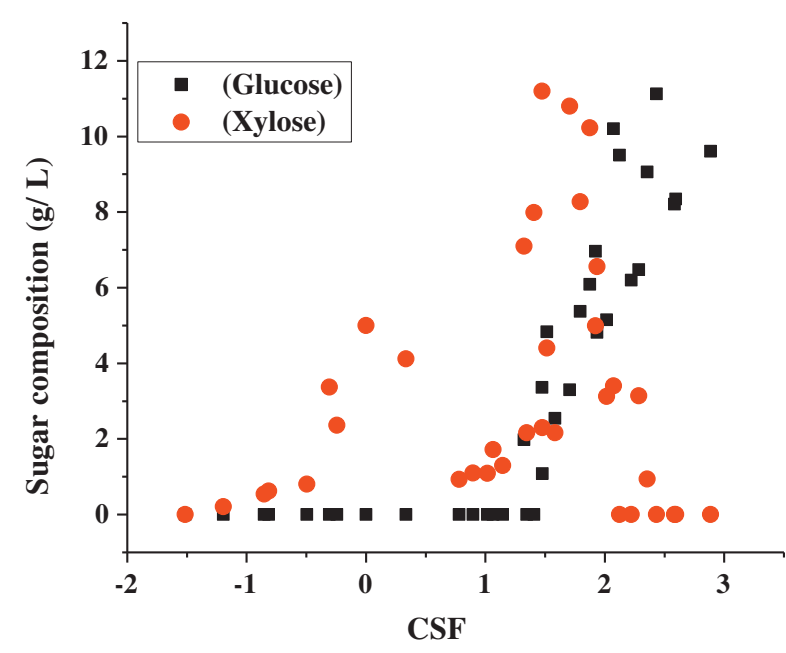

Fig. 1. Xylose and glucose composition in PBT shedding bark prehydrolysates (10\%, $\mathrm{w} / \mathrm{v}$ solid load) presented as a function of CSF.

media consisted of filter-sterilized hydrolysate containing $2 \mathrm{~g} \mathrm{~L}^{-1}$ $\mathrm{KH}_{2} \mathrm{PO}_{4}, 5 \mathrm{~g} \mathrm{~L}^{-1}$ yeast extract, $10 \mathrm{~g} \mathrm{~L}^{-1}$ peptone and $1 \mathrm{~g} \mathrm{~L}^{-1} \mathrm{MgSO}_{4}$. The $\mathrm{pH}$ was 5.05 . Fermentations were conducted with a working volume of $100 \mathrm{~mL}$ and were incubated at $30^{\circ} \mathrm{C}$ with slow agitation. Samples were taken at regular time intervals for measurement of biomass as well as glucose and ethanol concentrations.

\section{Results and discussion}

\subsection{Effect of pretreatment on composition of hydrolysate and} biomass morphology

\subsubsection{Effect of pretreatment on xylan dissolution}

The yields of sugars for both SCW and acid pretreated hydrolysates (prehydrolysates) are shown in Fig. 1. For SCW pretreatment at very low CSF $(-1.515$ to -0.853$)$, little xylose $(<5 \%$ xylan) was recovered in the prehydrolysates, while as CSF was increased to 0.0004 , the xylose yield reached $5.0 \mathrm{~g} \mathrm{~L}^{-1}$, which is about $28 \%$ of available xylan (Table 2). This does not reflect poor solublization of PBT xylan. Previous studies on using compressed hot water for pretreatment of lignocelluloses biomass from different sources indicated that the solubilized hemicelluloses appeared mainly in oligomeric form [27-31]. Our result yielded $>20 \%$ xylan dissolution in the absence of an acid catalyst (SCW) at a lower temperature $\left(140-160^{\circ} \mathrm{C}\right)$ in contrast to previous works using higher temperature $\left(>180^{\circ} \mathrm{C}\right)$ and compressed hot water $[27,29]$. Similarly when using dilute acid pretreatment at low CSF (0.78-1.347), little xylose was obtained ( $<5 \%$ xylan), which is less than the maximum recovery obtained from SCW pretreatment at a CSF of 0.0004 (Fig. 1). This unusual event indicates that the main factor among

Table 2

Chemical compositions of the native PBT shedding bark.

\begin{tabular}{ll}
\hline Component & Composition $^{\mathrm{a}}$ \\
\hline Glucan & 47.2 \\
Xylan & 17.4 \\
Galactan & $\mathrm{ND}$ \\
Extractives & 9.2 \\
Ash & 1.14 \\
Moisture & 5.37 \\
Acid insoluble lignin & 17.6 \\
Acid soluble lignin & 1.53 \\
\hline
\end{tabular}

\section{ND: not detected.}

a Percent composition on dry-weight basis. pretreatment variables in CSF was temperature. Xylose recovery increased with increasing CSF and peaked at a CSF of 1.475 , with a value of $11.2 \mathrm{~g} \mathrm{~L}^{-1}$, which is $64.4 \%$ of xylan. However, at CSF $>2.0$, xylose yield declined, presumably due to degradation. Hence dilute acid had better effect on xylan solubilization in comparison with the SCW for PBT bark. Carolina et al., [16] reported a comparison of pretreatment methods and the report indicate that dilute acid had better effect on solubilization of hemicelluloses than compressed hot water pretreatment.

During SCW pretreatment, temperature had the greatest impact $(p=0.002)$ on xylose recovery among the pretreatment variables. An increase in temperature from 120 to $160^{\circ} \mathrm{C}$ was accompanied with an increase in xylose yield from $0.21 \mathrm{~g} \mathrm{~L}^{-1}$ to $5.0 \mathrm{~g} \mathrm{~L}^{-1}$ in the prehydrolysate while less effect was observed for reaction time $(p=0.046)$. Similarly, at low $\mathrm{H}_{2} \mathrm{SO}_{4}$ concentration (0.5\%), comparable effect of temperature was observed from 120 to $140^{\circ} \mathrm{C}$. Further rise to $160^{\circ} \mathrm{C}$ reduced xylose recovery drastically. At $1 \%$ and $2 \% \mathrm{H}_{2} \mathrm{SO}_{4}$, temperature was still the most determinant factor $(p<0.01)$ on xylose yield with optimum values at 140 and $120^{\circ} \mathrm{C}$, respectively. Using $1 \% \mathrm{H}_{2} \mathrm{SO}_{4}$ at $140^{\circ} \mathrm{C}$, significantly higher $(p<0.01)$ xylose yield $\left(8.3 \mathrm{~g} \mathrm{~L}^{-1}\right)$ was obtained after $30 \mathrm{~min}$ pretreatment compared to $1.92 \mathrm{~g} \mathrm{~L}^{-1}$ at $15 \mathrm{~min}$. Further increasing reaction time to $60 \mathrm{~min}$ resulted in xylose degradation (about 2.65 fold loss). At the most acidic condition $\left(2 \% \mathrm{H}_{2} \mathrm{SO}_{4}\right)$, reaction time became a more important factor at both extreme ends of temperature $\left(120\right.$ and $\left.160^{\circ} \mathrm{C}\right)$. At $120^{\circ} \mathrm{C}$, xylose yield sharply increased from 1.72 to $10.8 \mathrm{~g} \mathrm{~L}^{-1}$ as reaction time progressed from 15 to $60 \mathrm{~min}$. However, extending reaction time from 30 to $60 \mathrm{~min}$ at $160^{\circ} \mathrm{C}$ significantly $(p<0.05)$ reduced the xylose yields. Indeed, pretreating PBT samples under extreme conditions (2\% $\mathrm{H}_{2} \mathrm{SO}_{4}, 160^{\circ} \mathrm{C}, 60 \mathrm{~min}$ ) showed complete degradation of xylose. High xylose yields were achieved when the pretreatment took place using $2 \% \mathrm{H}_{2} \mathrm{SO}_{4}$ at $120^{\circ} \mathrm{C}$ for $60 \mathrm{~min}$ or $2 \% \mathrm{H}_{2} \mathrm{SO}_{4}$ at $140{ }^{\circ} \mathrm{C}$ for $15 \mathrm{~min}$. For the lowest $\mathrm{H}_{2} \mathrm{SO}_{4}$ concentration (0.5\%), moderate temperature $\left(140^{\circ} \mathrm{C}\right)$ and 30 min hydrolysis time resulted higher xylose release with minor degradation.

\subsubsection{Effect of pretreatment on glucan dissolution}

Glucose yield increased with increasing CSF, which is an indication of cellulose disruption. These trends were observed in several previous lignocellulosic biomass pretreatment studies [32-34]. Glucan depolymerization apparently resulted in the release of monomeric glucose. Subcritical water prehydrolysate $(\mathrm{CSF} \leq 0.335)$ was free from monomeric glucose hence complete glucan recovery in pretreated solid residue was possible; however an increase in CSF was accompanied by an increase in glucose release. At a CSF of 1.475 , where xylose yield peaked, significant glucan depolymerization was witnessed; with a glucose recovery of $3.36 \mathrm{~g} \mathrm{~L}^{-1}$, which is about $7.15 \%$ of the available glucan. Glucose release kept increasing with increasing CSF. At a CSF of $\sim 2.123$, no xylose was detected while glucose yield reached $9.25 \mathrm{~g} \mathrm{~L}^{-1}$. Similar to xylan solublization, temperature had the greatest impact $(p=0.001)$ on glucan depolymerisation followed by reaction time and acid strength. For instance, at $0.5 \% \mathrm{H}_{2} \mathrm{SO}_{4}(\mathrm{pH} 1.1)$ and $30 \mathrm{~min}$, the glucose released increased by 5.15 -fold to $24.8 \%$ of the total glucan when temperature was raised from $140(\mathrm{CSF}=1.475)$ to $160^{\circ} \mathrm{C}(\mathrm{CSF}=2.074) . \mathrm{A}$ notable difference between solubilisation of the xylan and glucan fractions was the fact that the latter did not reach its potential maximum under the study conditions (Fig. 1). This glucan depolymerisation during pretreatment of PBT shedding bark requires further investigation. Söderström et al. [35] reported that up to $40 \%$ cellulose hydrolysis was possible for softwoods at high CSF (3.1-3.2), albeit at the expense of pentose sugars and accumulation of degradation products (furfural, formic acid). Moreover they reported that at CSF $>3.2$, glucose yield dramatically declined through degradation to HMF and levulinic acid. From results in 


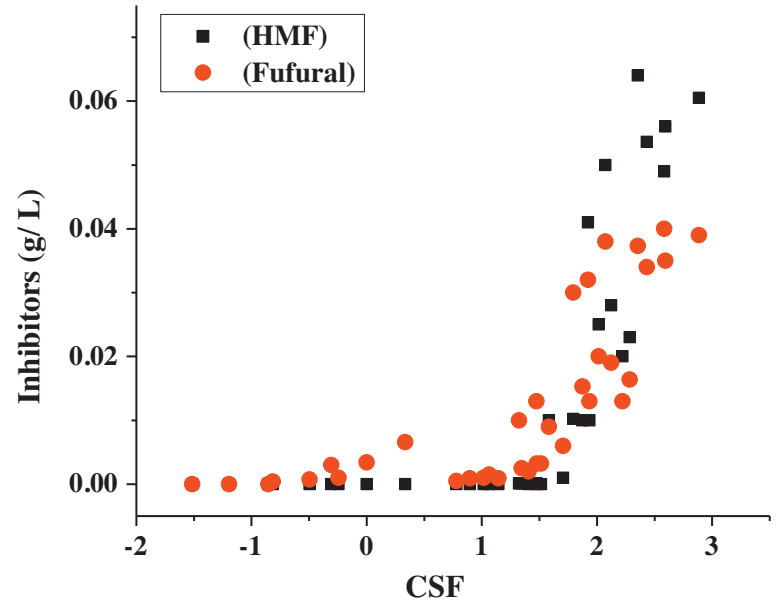

Fig. 2. Furfural and HMF composition in PBT shedding bark prehydrolysates (10\%, $\mathrm{w} / \mathrm{v}$ solid load) presented as a function of CSF

glucose release, it was observed that temperature had the most pronounced effect $(p<0.01)$ on glucose yield when implementing SCW or the most dilute acid pretreatment. However, reaction time had dominant effect $(p<0.01)$ at $2 \% \mathrm{H}_{2} \mathrm{SO}_{4}$. The degrading effect of temperature on glucose was not significant at the most acidic condition used in this study $\left(2 \% \mathrm{H}_{2} \mathrm{SO}_{4}\right)$, unlike in the case of xylose.

\subsubsection{Effect of pretreatment on inhibitors accumulation}

During acid pretreatments, various inhibitors may be formed, such as phenolics, furfural and HMF [36,37]. These inhibitory compounds originate from the release and subsequent degradation of carbohydrate and lignin. Formation of these compounds is directly proportional to pretreatment severity [38]. In Fig. 2, the formation of furfural and HMF, the two major degradation products of pentose and hexose sugars, is presented as a function of CSF. SCW prehydrolysate was free of detectable inhibitors or negligible accumulation of furfural at its highest CSF, while in dilute acid prehydrolysate the accumulation of furfural and HMF increased with increasing CSF. Treatment conditions which increased low level accumulation of furfural strongly correlated to conditions associated with the progression of xylose loss (CSF > 1.75). In contrast, the appearance of low level of HMF does not appear to correlate to any glucose loss during pretreatment but presumably results from the degradation of minor hexose sugars associated with the hemicelluloses fraction. These results support similar observations in the pretreatment of both hard and softwoods [32,35,39].

\subsubsection{Modeling fit}

The data of sugars and inhibitors were successfully modeled using cubic and quadratic polynomial multiple regression equations, which define predicted responses in terms of the independent variables:

$$
\begin{aligned}
\text { Xylose }= & 0.03+33.47 X_{1}-1.173 X_{2}+0.019 X_{3}-21.16 X_{2}^{2} \\
& -0.14 X_{1} X_{2}+7.21 X_{1}^{3}-5.6 X_{2}^{3} \\
\text { Glucose }= & 5.85+2.23 X_{1}+3.27 X_{2}+0.8 X_{3}-3.11 X_{1}^{2}+0.097 X_{2}^{2} \\
& -0.5 X_{3}^{2}+1.29 X_{1} X_{2}+0.74 X_{1} X_{3}-0.09 X_{2} X_{3} \\
\text { HMF }= & 0.017+0.0093 X_{1}+0.0192 X_{2}+0.006 X_{3}-0.0115 X_{1}^{2} \\
+ & 0.011 X_{2}^{2}-0.003 X_{3}^{2}+0.008 X_{1} X_{2}+0.0042 X_{1} X_{3} \\
+ & 0.0053 X_{2} X_{3}
\end{aligned}
$$

Table 3

ANOVA table of the adjusted models from SCW and dilute sulfuric acid pretreated PBT shedding bark.

\begin{tabular}{lcccl}
\hline Source & Sum of squares & DF & $F$ value & $P$-value \\
\hline Xylose & & & & \\
Model & 561.095 & 8 & 11.52 & 0.0000 \\
Residual & 47.6 & 28 & - & - \\
$R^{2}$ & 0.9593 & - & - & - \\
Glucose & & & & \\
Model & 416.65 & 9 & 14.01 & 0.0001 \\
Residual & 34.8 & 26 & - & - \\
$R^{2}$ & 0.9882 & - & - & - \\
HMF & & & & \\
Model & 128.44 & 9 & 11.62 & 0.0001 \\
Residual & 31.93 & 26 & - & - \\
$R^{2}$ & 0.9721 & - & - & - \\
Furfural & & & & 0.0001 \\
Model & 539.5 & 9 & 11.89 & - \\
Residual & 31.1 & - & - & - \\
$R^{2}$ & 0.9910 & & - & \\
\hline
\end{tabular}

Furfural $=0.0212+0.0064 X_{1}+0.0125 X_{2}+0.004 X_{3}-0.0097 X_{1}^{2}$

$$
\begin{aligned}
& +0.0023 X_{2}^{2}-0.005 X_{3}^{2}+0.004 X_{1} X_{2}+0.0026 X_{1} X_{3} \\
& +0.0022 X_{2} X_{3}
\end{aligned}
$$

where, $X_{1}$ is acid concentration, $X_{2}$ is temperature, $X_{3}$ is time.

The regression equations obtained from ANOVA ensured a satisfactory adjustment of the theoretical values to the experimental data (Table 3). The proportion of total variation attributed to each fit can be evaluated by the value of $R^{2}$ and Chauhan and Gupta [40] reported a value of $R^{2}>0.75$ which indicates the aptness of the model. The relationship between responses (sugars and inhibitors yield) and variables is visualized by the contour plot (Supplementary Material). The plots present the polynomial models which showed the response of the factors varied within their experimental range and holding the third factor at fixed center level. The contour plot of xylose and furfural (Fig. S1) shows that, at $1 \% \mathrm{H}_{2} \mathrm{SO}_{4}$ concentration (fixed at center level) xylan conversion to xylose is most favored at a pretreatment temperature of $137^{\circ} \mathrm{C}$ and a reaction time of $37 \mathrm{~min}$, but under harsher conditions $\left(>150^{\circ} \mathrm{C}\right.$, and $>50 \mathrm{~min}$ ) xylose conversion to furfural began to dominate. Similarly the xylose yield plot of pretreatment temperature and acid concentration when the time was kept at central value clearly shows that, the interaction of these two variables had a significant effect on response of xylose. In general the optimum condition for monomeric xylose is at moderate temperature $\left(135-140^{\circ} \mathrm{C}\right)$ and acidity $\left(0.5-1 \% \mathrm{H}_{2} \mathrm{SO}_{4}\right)$. If implementing higher acidity $(>1.5 \%$ $\left.\mathrm{H}_{2} \mathrm{SO}_{4}\right)$ it is important to use lower temperature $\left(<130^{\circ} \mathrm{C}\right)$ for higher xylose yield. However applying of simultaneously higher temperature $\left(>150{ }^{\circ} \mathrm{C}\right)$ and higher acidity $\left(>1.5 \% \mathrm{H}_{2} \mathrm{SO}_{4}\right)$ resulted in an increase of furfural accumulation. On the other hand, the response contour plots of glucose (Fig. S2) show that its solubility in prehydrolysis liquor depends on pretreatment severity, and did not reach its potential maximum in the model as also observed in the experiment. Although glucose and HMF yields share contour region, however more severity favored HMF accumulation. In general the optimum pretreatment condition of PBT shedding bark, which is characterized by high dissolution of xylan and low loss of glucan, was found to be $135-140^{\circ} \mathrm{C}, 30-40 \mathrm{~min}$ and $1 \%$ acid concentration.

\subsubsection{Effect of pretreatment on morphology of biomass}

SEM micrographs of native and pretreated PBT shedding bark sample are shown in Fig. 3. The native sample displayed a well-separated macrofibrils with smooth surface and length and diameter of $150-300 \mu \mathrm{m}$ and $5-10 \mu \mathrm{m}$, respectively, indicating a 

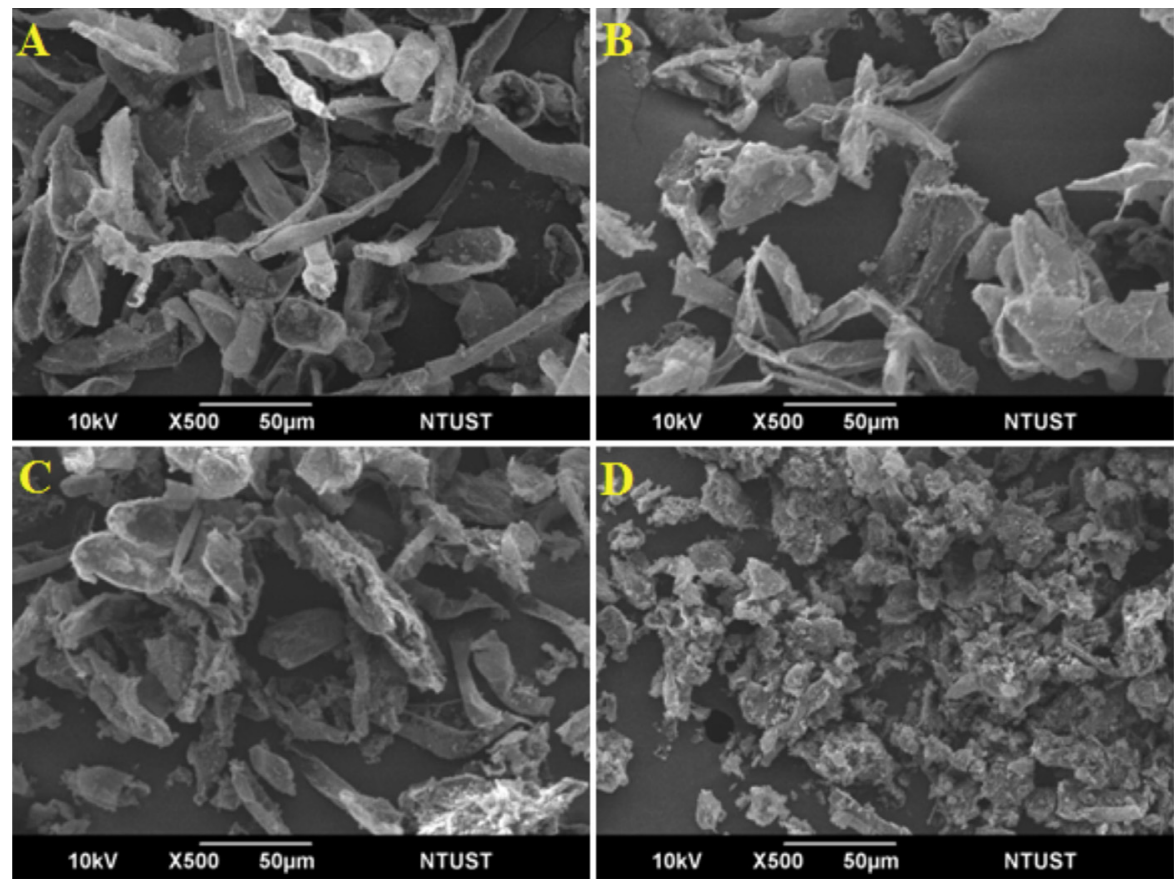

Fig. 3. SEM images comparing the morphology of PBT shedding bark (A: native, B: pretreated at CSF -0.495 , C: pretreated at CSF 1.795 and D: pretreated at CSF 1.935 ) samples at $500 \times$ and $10 \mathrm{kV}$.

highly ordered surface structure (Fig. 3A). The pretreated sample showed morphological changes on macrofibers (Fig. 3B-D). Higher pretreatment severity was accompanied with the reduction in macrofibrils size, agglomeration and exposed more internal areas in the biomass than the native one. After pretreatment at low CSF $(-0.495)$, the macrofibrils are still well separated and their diameters are almost the same, but the lengths of macrofibrils dropped and lost the smooth surface (Fig. 3B). Under moderate severe condition $(\mathrm{CSF}=1.795)$, some agglomerate of macrofibrils appeared and their lengths are reduced and shrunken in size (Fig. 3C) which indicates depolymerization of the reactive cellulose region. Samir et al. [41] found out that under controlled conditions, hydrolysis may remove the amorphous region of cellulose fiber before crystalline region. At high severe condition ( $C S F=1.935)$, agglomeration of macrofibrils increased greatly (Fig. 3D). Zhao et al. [42] proposed that when macrofibrils lose amorphous cellulose, the remaining microfibrils bundles have large surface potential, which could drive the agglomeration to lower the system energy. Alternatively, acid catalyzed intermolecular surface dehydration could also result in agglomerization. In general SEM shows that the long macrofibrils of PBT bark dissociated by the pretreatment were fine, and had smaller average size and more roughness and surface area than the untreated bark. Moreover, the smooth and contiguous surface of the original PBT bark was perforated by pretreatment. The porosity in pretreated fibrils greatly increased the enzyme-accessible surface area.

\subsection{Enzymatic hydrolysis of pretreated bark}

Pretreatment typically leads to degradation of hemicelluloses into sugars (mostly xylose) and solid residues with modified surface morphology, which is more accessible to enzymatic hydrolysis. Although high conversion yield can be realized by applying high enzyme loading following biomass pretreatment, enzyme dose need to be significantly reduced to make a conversion process commercially attractive [43]. Thus pretreatment conditions and subsequent enzymatic hydrolysis must be optimized for maximum sugar release with minimum amount of enzyme. In this study, cellulase to $\beta$-glucosidase (Novozym 188) at a Filter Paper Unit (FPU): Cellobiase Unit (CBU) of 1:2 combinations ratio was implemented [44]. $\beta$-Glucosidase was used to supplement the insufficient $\beta$-glucosidase activity in cellulases. The two enzymes cooperate in a synergistic fashion to degrade the substrate. The success of enzymatic hydrolysis generally depends in part on the pretreatment's capacity to remove cellulase-specific barriers [45]. To evaluate the effectiveness of pretreatment on cellulose to glucose conversion, pretreated slurries were subsequently used in trials with fixed enzyme activity dose. Excess enzyme combination loading (33 FPU and $66 \mathrm{CBU}$ per $\mathrm{g}$ of pretreated dry biomass) and prolonged reaction time $(72 \mathrm{~h})$ was implemented to exclude the effect of enzyme and time limitation on sugar production.

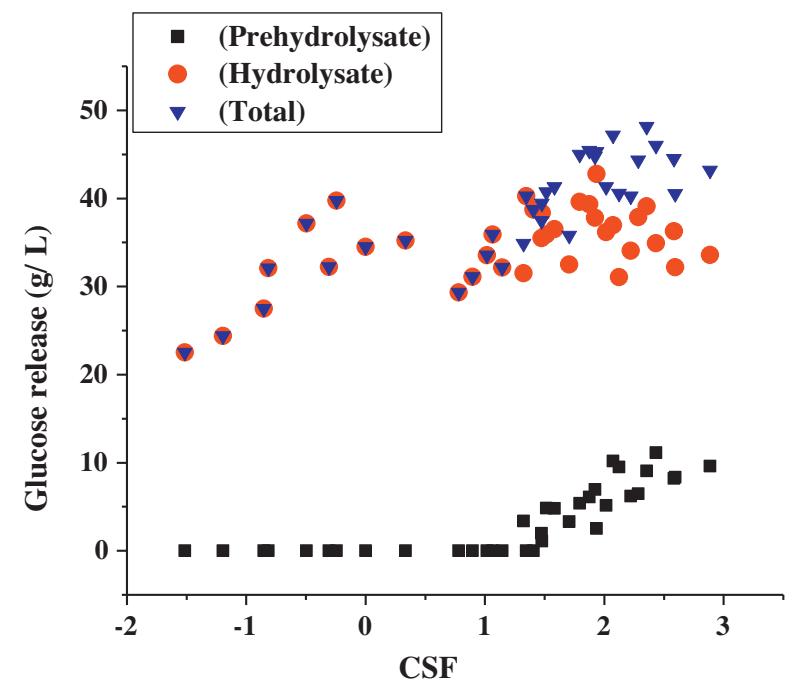

Fig. 4. Glucose composition ( $\mathrm{g} \mathrm{L}^{-1}$ ) in hydrolysates obtained after PBT shedding bark pretreatment ( $10 \%, \mathrm{w} / \mathrm{v}$ solid load) and enzyme saccharification $\left(50^{\circ} \mathrm{C} ; \mathrm{pH} 5.2 ; 48 \mathrm{~h}\right)$ presented as a function of CSF. 
Table 4

Typical examples of the pretreatment conditions and the results obtained in this work and in related studies.

\begin{tabular}{|c|c|c|c|c|c|c|c|c|}
\hline \multirow[t]{2}{*}{ Biomass } & \multirow[t]{2}{*}{ Pretreatment } & \multicolumn{4}{|c|}{ Prehydrolysate composition } & \multirow[t]{2}{*}{ Cellulase $^{\mathrm{c}}$} & \multirow{2}{*}{$\begin{array}{l}\text { Hydrolysate } \\
\text { glucose }^{\mathrm{d}}\end{array}$} & \multirow[t]{2}{*}{ Reference } \\
\hline & & Xylose $^{\mathrm{a}}$ & Glucose $^{\mathrm{a}}$ & $\mathrm{HMF}^{\mathrm{b}}$ & Furfural $^{\mathrm{b}}$ & & & \\
\hline Salix, wood chips & Steam explosion at $200^{\circ} \mathrm{C}, 0.25 \% \mathrm{H}_{2} \mathrm{SO}_{4}$ & 36 & 4 & 0.4 & 1.8 & 15 & 81 & [47] \\
\hline Spruce, wood chips & Steam explosion at $200{ }^{\circ} \mathrm{C}, 2.5 \% \mathrm{SO}_{2}$ & - & 17 & 0.55 & 0.31 & 15 & 50 & [48] \\
\hline Poplar & Organosolv at $180^{\circ} \mathrm{C}, 1.25 \% \mathrm{H}_{2} \mathrm{SO}_{4}, 50 \%$ ethanol & 50 & 1.2 & 0.45 & 0.1 & 20 & 82 & {$[49]$} \\
\hline Eucalyptus & Dilute acid $0.75 \% \mathrm{H}_{2} \mathrm{SO}_{4}$ at $160^{\circ} \mathrm{C}$ & 77.3 & 8.3 & 0.13 & 1.37 & 20 & 76 & {$[50]$} \\
\hline Paper bark tree & Dilute acid $0.5 \% \mathrm{H}_{2} \mathrm{SO}_{4}$ at $140^{\circ} \mathrm{C}(\mathrm{CSF}=1.475)$ & 64.4 & 7.17 & $<0.01$ & 0.015 & 33 & 92 & This work \\
\hline Paper bark tree & Subcritical water at $160^{\circ} \mathrm{C}(\mathrm{CSF}=0.0004)$ & 28 & 0.1 & ND & $<0.01$ & 33 & 85 & This work \\
\hline
\end{tabular}

ND: not detected.

a Sugars dissolved (monomers only) in liquor during pretreatment, reported in weight percent (wt.\%) of native biomass composition.

b Inhibitors concentration ( $\left.\mathrm{g} \mathrm{L}^{-1}\right)$ in liquor during pretreatment.

c FPU (filter paper unit) per g substrate.

d Enzymatic hydrolysis glucose yield; reported in weight percent (wt.\%) of original glucose in wood.

Enzyme hydrolysis of SCW pretreated material at its least severity conditions (CSF from -1.515 to -0.853 ) yielded moderate conversion of available glucan, with maximum reaching about $52 \%$ (24.4 g glucose $\left.\mathrm{L}^{-1}\right)$. These are better than the un-pretreated samples which yielded only $31 \%$ conversion. Lower CSF $(-0.495$ to -0.244 ) of SCW pretreated hydrolysate resulted in $\geq 85 \%$ recovery of available glucan into glucose (Fig. 4). Similarly, dilute acid pretreatment enhanced enzymatic hydrolysis of cellulose and release of monomeric glucose. A close look at data from saccharification only shows that proximate results were obtained using SCW (CSF $>-0.816)$ and dilute acid pretreatments. Implementing dilute acid pretreatment at $\mathrm{CSF} \geq 1.75$ the total recovered glucose reach a plateau of $43-48 \mathrm{~g} \mathrm{~L}^{-1}$, which indicates complete solublization of available glucan in the biomass. The small difference among samples is attributed to the accumulation of inhibitors during pretreatment and unavailability of glucan.

For PBT shedding bark pretreated by dilute acid or SCW, although significant difference was observed in the removal of hemicelluloses, equivalent amount of glucose was obtained after enzymatic hydrolysis. Therefore, SCW can be considered as a better alternative for pretreatment PBT shedding bark since it has advantages in environmentally friendly, free from inhibitors accumulation, and no need for detoxification of hydrolysate. Moreover SCW pretreatment sounds economically feasible and simple to implement when compared to other biomass pretreatment methods. For instance the typical organosolv pretreatment of woody biomass requires high temperature $\left(160-190^{\circ} \mathrm{C}\right)$ and high ethanol concentration (40-60\%) [46]. In organosolv pretreatment, despite good cellulose conversion, hemicelluloses recovery was low because of sugar decomposition at high temperatures in the presence of acid; hence it requires extensive detoxification due to the high concentration of inhibitors such as furfural and HMF (Table 4). Furthermore, complete solvent (ethanol) recovery is a critical issue in process economy. Similarly, the most commonly used steam pretreatment (acid catalyzed steam explosion) method also has drawbacks such as inhibitor accumulation, relatively
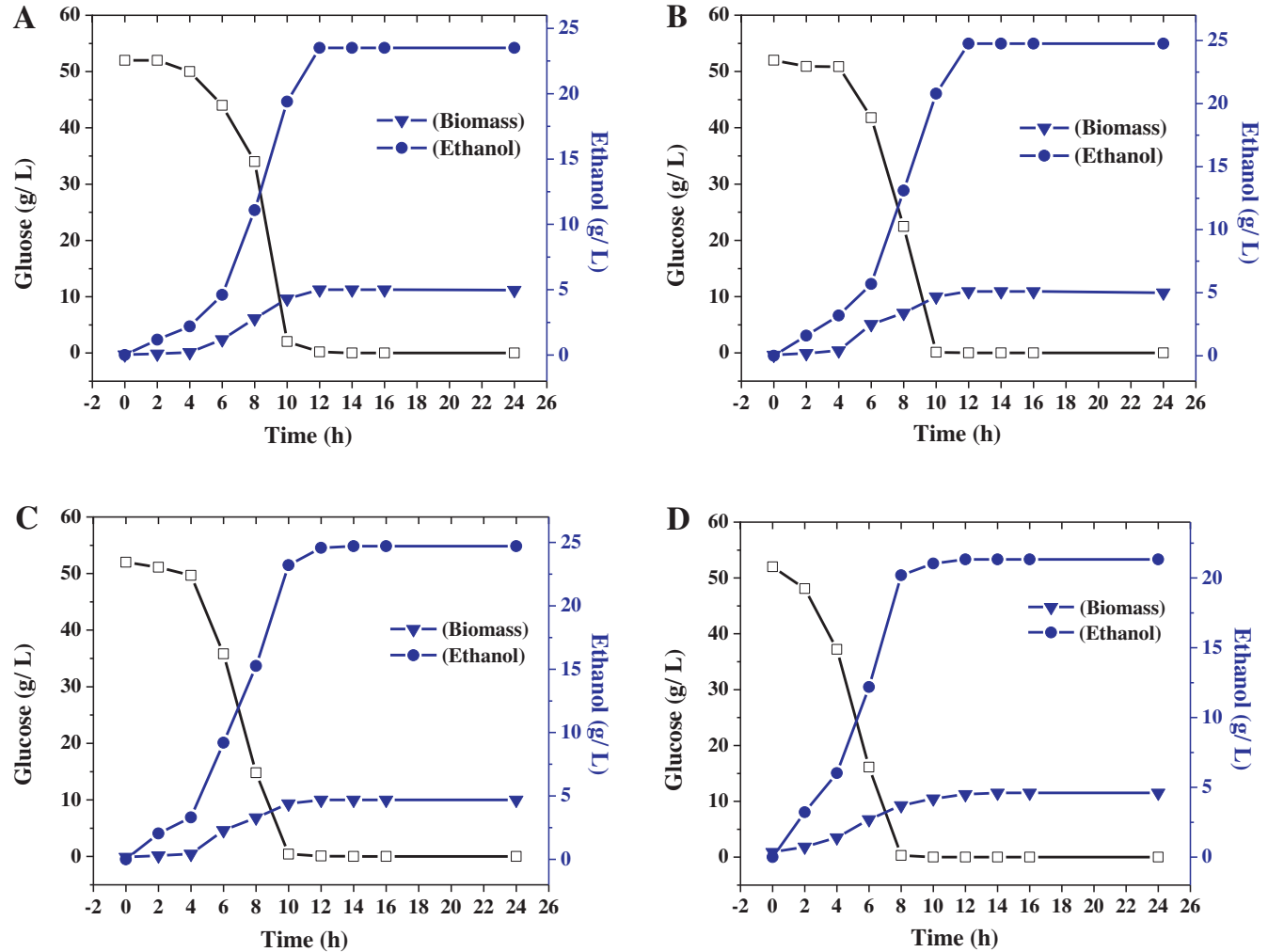

Fig. 5. Time courses of glucose consumption, ethanol and yeast biomass production at inoculums size of $1 \%$ (A), $2 \%$ (B), $5 \%$ (C) and $10 \%$ (D) (v/v) Saccharomyces cerevisiae. 
low sugar recovery especially when applied to softwood and energy-intensive (operation temperature above $200^{\circ} \mathrm{C}$ ). In general, SCW pretreatment is advantageous in that very low levels of fermentation inhibitors than those generated by organosolv, steam explosion and dilute acid pretreatments. Moreover the milder temperature $\left(120-160^{\circ} \mathrm{C}\right)$ used requires lower energy consumption and prevents glucan and xylan degradation, resulting in better monomeric sugar recovery $(>85 \%)$ in saccharification. In addition, since no chemicals is required making SCW treatment an environmentally benign and economical approach.

\subsection{Hydrolysate fermentation}

Identifying optimum inoculums size is important in reducing the production cost of cellulosic ethanol. In this study the fermentation of hydrolysate with various $S$. cerevisiae seed cultures was performed. The time courses of ethanol production, residual glucose and dry cell biomass during fermentation are shown in Fig. 5. At low inoculums sizes $(1-5 \%, v / v)$, ethanol production rate in the early phase of culture was slow but rapidly increased after $5 \mathrm{~h}$. This phenomenon is more pronounced at $1 \%$ inoculum. At high inoculum size $(10 \%, v / v)$, fast glucose consumption and ethanol production were observed.

In the first $4 \mathrm{~h}$, both biomass and ethanol concentrations changed little since cells were adapting to the new environment. After that, biomass increased rapidly due to fast utilization of glucose and nitrogen. Between 6 and $10 \mathrm{~h}$ sharp increases in biomass and ethanol were observed while glucose decreased rapidly. After $10 \mathrm{~h}$ a gradual decrease in xylose concentration was observed (data not shown) with negligible change on ethanol concentration, which indicated that the yeast may consume xylose under glucose stress condition. Biomass concentration remained fairly constant after $12 \mathrm{~h}$ and fermentation was almost completed after $12 \mathrm{~h}$.

The highest ethanol concentration was $24.7 \mathrm{~g} \mathrm{~L}^{-1}$, corresponding to a conversion of $0.475 \mathrm{~g} \mathrm{~g}^{-1}$ glucose ( $91 \%$ ethanol yield) when using $2-5 \%(\mathrm{v} / \mathrm{v})$ yeast inoculum size. At $1 \%$ inoculum, the yield was a bit lower (87\%). In the case of the highest inoculums size $(10 \%, v / v)$, glucose consuming and fermentation time was shorter $(8 \mathrm{~h})$, while conversion reduced to $0.41 \mathrm{~g} \mathrm{~g}^{-1}$ glucose $(80.4 \%$ ethanol yield). Turhan et al. [51] reported that $3 \%(\mathrm{v} / \mathrm{v})$ inoculum size was optimum for ethanol production from carob. Similarly, Sharma et al. [52] showed an inoculum level of $3 \% \mathrm{v} / \mathrm{v}$ as optimum for maximum ethanol production from sunflower hulls hydrolysate. A report by Fadel [53] showed that increasing inoculum size up to $4 \%$ increased production of ethanol from starchy industrial waste, which is also in agreement with this study.

\section{Conclusion}

M. leucadendron shedding barks have higher glucan and xylan components. Although optimal conditions for glucan and xylan solubilzation were found to be different, significant glucose recovery was detected under moderate severity conditions ( $C S F \geq 1.514$ ). The optimum pretreatment conditions of PBT shedding bark, which is characterized by high dissolution of hemicellulose and low loss of cellulose, is at $1 \%(\mathrm{v} / \mathrm{v}) \mathrm{H}_{2} \mathrm{SO}_{4}$ acid concentration, $135-140^{\circ} \mathrm{C}$ pretreatment temperature and 30-40 min pretreatment time. Implementing environmentally friendly subcritical water pretreatment at very low severity condition $(\mathrm{CSF} \leq 0.335)$ on PBT biomass, $85 \%$ of glucan solubilization can be achieved after enzymatic hydrolysis. Fermentation trials confirmed the feasibility to convert the hydrolysate into ethanol with high yield (91\%) at lower inoculums, which implies paper bark tree shedding is a promising feedstock for bioethanol production.

\section{Acknowledgments}

The authors would like to acknowledge the National Science Council of Taiwan (NSC100-2623-E-011-001-ET) and National Taiwan University of Science and Technology (100H451403) for financing this work.

\section{Appendix A. Supplementary data}

Supplementary data associated with this article can be found, in the online version, at http://dx.doi.org/10.1016/j.bej.2013.03.008.

\section{References}

[1] T.M. Fenning, C. Walter, K.M.A. Gartland, Forest biotech and climate change, Nat. Biotechnol. 26 (2008) 615-617.

[2] G. Garrote, H. Domínguez, J.C. Parajó, Hydrothermal processing of lignocellulosic materials, Eur. J. Wood Prod. 57 (1999) 191-202.

[3] A.T.W.M. Hendricks, G. Zeeman, Pretreatments to enhance the digestibility of lignocellulosic biomass, Bioresour. Technol. 100 (2009) 10-18.

[4] C.E. Wyman, What is (and is not) vital to advancing cellulosic ethanol, Trends Biotechnol. 25 (2007) 153-157.

[5] T. Eggman, R.T. Elander, Process and economic analysis of pretreatment technologies, Bioresour. Technol. 96 (2005) 2019-2025.

[6] S.D. Mansfield, C. Mooney, J.N. Saddler, Substrate and enzyme characteristics that limit cellulose hydrolysis, Biotechnol. Prog. 15 (1999) 804-816.

[7] S.P. Chundawat, B. Venkatesh, B.E. Dale, Effect of particle size based separation of milled corn stover on AFEX pretreatment and enzymatic digestibility, Biotechnol. Bioeng. 96 (2007) 219-231.

[8] N. Mosier, C. Wyman, B. Dale, R. Elander, Y.Y. Lee, M. Holtzapple, M.R. Ladisch, Features of promising technologies for pretreatment of lignocellulosic biomass, Bioresour. Technol. 96 (2005) 673-686.

[9] A. Kruse, E. Dinjus, Hot compressed water as reaction medium and reactant properties and synthesis reactions, J. Supercrit. Fluid. 39 (2007) 362-380.

[10] Y.A. Tsigie, L.H. Huynh, I.N. Ahmed, Y.H. Ju, Maximizing biodiesel production from Yarrowia lipolytica Po1g biomass using subcritical water pretreatment, Bioresour. Technol. 111 (2012) 201-207.

[11] M. Bicker, S. Endres, L. Ott, H. Vogel, Catalytical conversion of carbohydrates in subcritical water: a new chemical process for lactic acid production, J. Mol. Catal. A: Chem. 239 (2005) 151-157.

[12] A. Kruse, A. Gawlik, Biomass conversion in water at $330-410^{\circ} \mathrm{C}$ and $30-50 \mathrm{MPa}$. Identification of key compounds for indicating different chemical reaction pathways, Ind. Eng. Chem. Res. 42 (2002) 267-279.

[13] F. Salak Asghari, H. Yoshida, Acid-catalyzed production of 5-hydroxymethyl furfural from D-fructose in subcritical water, Ind. Eng. Chem. Res. 45 (2006) 2163-2173.

[14] M. Sasaki, B. Kabyemela, R. Malaluan, S. Hirose, N. Takeda, T. Adschiri, K. Arai, Cellulose hydrolysis in subcritical and supercritical water, J. Supercrit. Fluids. 13 (1998) 261-268.

[15] H. Yoshida, M. Terashima, Y. Takahashi, Production of organic acids and amino acids from fish meat by sub-critical water hydrolysis, Biotechnol. Progr. 15 (1999) 1090-1094.

[16] C.M. Carolina, J.G. Arturo, E.H. Mahmoud, A comparison of pretreatment methods for bioethanol production from lignocellulosic materials, Process. Saf. Environ. 90 (2012) 189-202.

[17] M.J. Taherzadeh, K. Karimi, Enzyme-based hydrolysis processes for ethanol from lignocellulosic material: a review, BioResources 2 (2007) 707-738.

[18] L.P. Ramos, The chemistry involved in the steam treatment of lignocellulosic materials, Quim. Nova 26 (2003) 863-871.

[19] B.C. Saha, L.B. Iten, M.A. Cotta, Y.V. Wu, Dilute acid pretreatment, enzymatic saccharification and fermentation of wheat straw to ethanol, Process Biochem. 40 (2005) 3693-3700

[20] B.S. Baboukani, M. Vossoughi, I. Alemzadeh, Optimization of dilute-acid pretreatment conditions for enhancement sugar recovery and enzymatic hydrolysis of wheat straw, Biosyst. Eng. 111 (2012) 166-174.

[21] R.P. Overend, E. Chornet, Fractionation of lignocellulosics by steam-aqueous pretreatments, Philos. Trans. R. Soc. Lond Ser. A: Math. Phys. Eng. Sci. 321 (1987) 523-536.

[22] H. Chum, D. Johnson, S. Black, R. Overend, Pretreatment-catalyst effects and the combined severity parameter, Appl. Biochem. Biotechnol. 24-25 (1990) $1-14$.

[23] R. Sindhu, P. Binod, S. Nagalakshmi, K.U. Janu, K.V. Sajna, N. Kurien, R.K. Sukumaran, A. Pandey, Formic acid as a potential pretreatment agent for conversion of sugarcane bagasse to ethanol, Appl. Biochem. Biotechnol. 162 (2010) 2313-2323.

[24] G. Cheng, P. Varanasi, R. Arora, V. Stavila, B.A. Simmons, M.S. Kent, S. Singh, Impact of ionic liquid pretreatment conditions on cellulose crystalline structure using 1-ethyl-3-methylimidazolium acetate, J. Phys. Chem. B 116 (2012) 10049-10054. 
[25] A. Sluiter, B. Hames, R. Ruiz, C. Scarlata, J. Sluiter, D. Templeton, D. Crocker Determination of structural carbohydrates and lignin in biomass, NREL. Technical Report NREL/TP-510-42618 (2008) 1-18.

[26] A. Sluiter, R. Ruiz, C. Scarlata, J. Sluiter, D. Templeton, Determination of extractives in biomass, NREL. Technical Report NREL/TP-510-42619 (2005) 1-8.

[27] S.G. Allen, D. Schulman, J. Lichwa, M.J. Antal, M. Laser, L.R. Lynd, A comparison between hot liquid water and steam fractionation of corn fiber, Ind. Eng. Chem. Res. 40 (2001) 2934-2941.

[28] F. Carvalheiro, M.P. Esteves, J.C. Parajo, H. Pereira, F.M. Girio, Production of oligosaccharides by autohydrolysis of brewery's spent grain, Bioresour. Technol. 91 (2004) 93-100.

[29] A. Romani, G. Garrote, J.L. Alonso, J.C. Parajo, Bioethanol production from hydrothermally pretreated Eucalyptus globulus wood, Bioresour. Technol. 10 (2010) 8706-8712.

[30] G. Garrote, H. Dominguez, J.C. Parajo, Mild autohydrolysis and environmentally friendly technology for xylooligosaccharide production from wood, J. Chem. Technol. Biotechnol. 74 (1999) 1101-1109.

[31] M.A. Kabel, F. Carvalheiro, G. Garrote, E. Avgerinos, E. Koukios, J.C. Parajo, F.M Girio, H.A. Schols, A.G.J. Voragen, Hydrothermally treated xylan rich byproducts yield different classes of xylo-oligosaccharides, Carbohyd. Polym. 50 (2002) 47-56.

[32] A. Emmel, A.L. Mathias, F. Wypych, L.P. Ramos, Fractionation of Eucalyptus grandis chips by dilute acid-catalysed steam explosion, Bioresour. Technol. 86 (2003) 105-115.

[33] M.A. Kabel, G. Bos, J. Zeevalking, A.G.J. Voragen, H.A. Schols, Effect of pretreatment severity on xylan solubility and enzymatic breakdown of the remaining cellulose from wheat straw, Bioresour. Technol. 98 (2007) 2034-2042.

[34] T.A. Lloyd, C.E. Wyman, Combined sugar yields for dilute sulfuric acid pretreatment of corn stover followed by enzymatic hydrolysis of the remaining solids, Bioresour. Technol. 96 (2005) 1967-1977.

[35] J. Söderström, L. Pilcher, M. Galbe, G. Zacchi, Two-step steam pretreatment of softwood by dilute $\mathrm{H}_{2} \mathrm{SO}_{4}$ impregnation for ethanol production, Biomass Bioenergy 24 (2003) 475-486.

[36] Y. Kim, E. Ximenes, N.S. Mosier, M.R. Ladisch, Soluble inhibitors/deactivators of cellulase enzymes from lignocellulosic biomass, Enzyme Microb. Technol. 48 (2011) 408-415.

[37] E. Palmqvist, B. Hahn-Hägerdal, Fermentation of lignocellulosic hydrolysates. I: inhibition and detoxification, Bioresour. Technol. 74 (2000) 17-24

[38] C. Tengborg, K. Stenberg, M. Galbe, G. Zacchi, S. Larsson, E. Palmqvist, B. HahnHägerdal, Comparison of $\mathrm{SO}_{2}$ and $\mathrm{H}_{2} \mathrm{SO}_{4}$ impregnation of softwood prior to steam pretreatment on ethanol production, Appl. Biochem. Biotechnol. 70-72 (1998) 3-15.

[39] S. McIntosh, T. Vancov, J. Palmer, M. Spain, Ethanol production from Eucalyptus plantation thinning, Bioresour. Technol. 110 (2012) 264-272.
[40] B. Chauhan, R. Gupta, Application of statistical experimental design for optimization of alkaline protease production from Bacillus sp. RGR-14, Process Biochem. 39 (2004) 2115-2122.

[41] M.A.S.A. Samir, F. Alloin, A. Dufresne, Review of recent research into cellulosic whiskers, their properties and their application in nanocomposite field, Biomacromolecules 6 (2005) 612-626.

[42] H. Zhao, J.H. Kwak, Y. Wang, J.A. Franz, J.M. White, J.H. Holladay, Effects of crystallinity on dilute acid hydrolysis of cellulose by cellulose ball-milling study, Energy Fuel 20 (2006) 807-811.

[43] D. Gao, N. Uppugundla, S.P.S Chundawat, X. Yu, S. Hermanson, K. Gowda, P. Brumm, D. Mead, V. Balan, B.E. Dale, Hemicellulases and auxiliary enzymes for improved conversion of lignocellulosic biomass to monosaccharides, Biotechnol. Biofuels 4 (2011) 1-11.

[44] A. Berlin, N. Gilkes, D. Kilburn, R. Bura, A. Markov, A. Skomarovsky, O. Okunev, A. Gusakov, V. Maximenko, D. Gregg, A. Sinitsyn, J. Saddler, Evaluation of novel fungal cellulase preparations for ability to hydrolyze softwood substrates evidence for the role of accessory enzymes, Enzyme Microb. Technol. 37 (2005) 175-184.

[45] T. Jeoh, C. Ishizawa, M. Davis, M. Himmel, W. Adney, D. Johnson, Cellulase digestibility of pretreated biomass is limited by cellulose accessibility, Biotechnol. Bioeng. 98 (2007) 112-122.

[46] J.Y. Zhu, X.J. Pan, Woody biomass pretreatment for cellulosic ethanol production: technology and energy consumption evaluation, Bioresour. Technol. 101 (2010) 4992-5002.

[47] P. Sassner, C.G. Martensson, M. Galbe, G. Zacchi, Steam pretreatment of $\mathrm{H}_{2} \mathrm{SO}_{4}$ impregnated Salix for the production of bioethanol, Bioresour. Technol. 99 (2008) 137-145.

[48] S. Monavari, M. Gable, G. Zacchi, Impact of impregnation time and chip size on sugar yield in pretreatment of softwood for ethanol production, Bioresour. Technol. 100 (2009) 6312-6316.

[49] X.J. Pan, N. Gilkes, J. Kadla, K. Pye, S. Saka, D. Gregg, K. Ehara, D. Xie, D. Lam, J. Saddler, Bioconversion of hybrid poplar to ethanol and co-products using an organosolv fractionation process: optimization of process yields, Biotechnol. Bioeng. 94 (2006) 851-861.

[50] W. Wei, S. Wu, L. Liu, Enzymatic saccharification of dilute acid pretreated eucalyptus chips for fermentable sugar production, Bioresour. Technol. 110 (2012) 302-307.

[51] I. Turhan, K.L. Bialka, A. Demirci, M. Karhan, Ethanol production from carob extract by using Saccharomyces cerevisiae, Bioresour. Technol. 101 (2010) 5290-5296.

[52] S.K. Sharma, K.L. Kalra, G.S. Kocher, Fermentation of enzymatic hydrolysate of sunower hulls for ethanol production and its scale-up, Biomass Bioenergy 27 (2004) 399-402.

[53] M. Fadel, Alcohol production from potato industry starchy waste, Egypt. J. Microbiol. 35 (2000) 273-287. 